\title{
Protective effects of vitamin $E$ against hypercholesterolemia-induced age-related diseases
}

\author{
Betul Catalgol · Nesrin Kartal Ozer
}

Received: 23 March 2011/Accepted: 29 April 2011/Published online: 18 May 2011

(C) Springer-Verlag 2011

\begin{abstract}
Hypercholesterolemia is a major risk factor for age-related diseases such as atherosclerosis and Alzheimer's disease (AD). Changes in human plasma cholesterol levels results from the interaction between multiple genetic and environmental factors. The accumulation of excess cholesterol in blood vessels leads to atherosclerosis. Many studies on this field show that differential expression of oxidative stress-related proteins, lipid metabolism-related enzymes, and receptors response to atherogenic diet. Additionally, excess brain cholesterol has been associated with increased formation and deposition of amyloid- $\beta$ peptide from amyloid precursor protein which may contribute to the risk and pathogenesis of $\mathrm{AD}$. To consider genetically, more than 50 genes have been reported to influence the risk of late-onset AD. Some of these genes might be also important in cholesterol metabolism and transport. Epidemiological studies have shown an association between high intake and high serum concentrations of antioxidant vitamins like vitamin $\mathrm{E}$ and lower rates of ischemic heart diseases. It has been known that vitamin $\mathrm{E}$ also inhibits smooth muscle cell proliferation by nonantioxidant mechanism. On the basis of the previous results, vitamin $\mathrm{E}$ has been accepted as an important protective factor against hypercholesterolemia-induced agerelated diseases.
\end{abstract}

This paper is part of a Special Issue entitled "Tocotrienols in health and disease" (Guest editors: Bharat B. Aggarwal and Kalaniti Nesaretnam)".

B. Catalgol · N. K. Ozer $(\bowtie)$

Department of Biochemistry, Faculty of Medicine,

Marmara University, 34668 Haydarpasa, Istanbul, Turkey

e-mail: nkozer@marmara.edu.tr
Keywords Alzheimer's disease - Atherosclerosis · Hypercholesterolemia · Vitamin E · Tocotrienol

\section{Introduction}

Biological aging is a process, results in the loss of cellular functions that leads to the development of related neurodegenerative and cardiovascular diseases. Therefore, understanding the mechanisms underlying aging is necessary to develop therapeutic interventions against age-related diseases. Following several studies in many years, oxidative damage is strongly implicated in the pathogenesis of neurodegenerative and cardiovascular diseases including Alzheimer's disease and atherosclerosis (Squier 2001).

Atherosclerosis, a chronic inflammatory disease which is characterized by the accumulation of plasma lipoproteins that carry cholesterol and triglycerides in the arteries, is one of the major causes of morbidity and mortality worldwide. This accumulation results in the proliferation of certain cell types within the arterial wall (Stocker and Keaney 2004). In the atherosclerotic process, macrophage foam cells are formed with the rapid transformation of phagocytic monocytes penetrated into the subendothelial space and atherogenic lipoproteins like modified low-density lipoprotein (LDL) are uptaken by receptor-mediated endocytosis mechanism (Osterud and Bjorklid 2003; Schmitz and Grandl 2007). Following the endocytosis, these cells have an appearance loaded with lipid droplets rich in cholesteryl esters. These foam cells also known as "fatty streaks" and adaptive thickening of the intima are accepted as the main visible lesions at the early stage of the pathogenesis (Steinberg 2009). Cellular uptake of the atherogenic lipids and lipoproteins are mediated by several receptors, and CD36 takes the most important place in the 
scavenger receptors playing role in atherosclerotic process (Stocker and Keaney 2004; Schmitz and Grandl 2007).

Alzheimer is another important age-related disease, most common form of adult onset dementia. Neuropathology of $\mathrm{AD}$ arises from numerous biochemical changes such as cholinergic deficits (Francis et al. 1999); neuronal metabolic insult (glutamate induced excitotoxicity) (Masliah et al. 1996); and oxidative stress or damage such as lipid peroxidation and protein oxidation (Nunomura et al. 2006). AD progression and memory loss involves various cellular anomalies such as: (1) accumulation of extracellular neuritic plaques of amyloid- $\beta$ peptide (A $\beta$ ) (Butterfield et al. 1996); (2) intracellular neurofibrillary tangles (NFTs); (3) proliferation of astrocytes, synaptic loss; and (4) progressive loss of neurons and microglial activation (Markesbery and Lovell 2007; Sultana et al. 2006).

\section{Basic mechanisms in the cholesterol-induced age-related diseases}

Denham Harman introduced the free radical theory of aging in 1956 and proposed that aging results from random deleterious damage to tissues by free reactive species (RS) damage cellular components such as proteins, lipids, carbohydrates, and nucleic acids and several products are known to be produced(Nordberg and Arnér 2001). The main investigated products are malondialdehyde (MDA) and 4-hydroxynonenal (HNE) for lipid peroxidation, 8-hydroxydeoxyguanosine for DNA oxidation and protein carbonyls, nitrotyrosines for protein oxidation (Griffiths et al. 2002; Catalgol and Grune 2009).

Lipid peroxidation and LDL oxidation induced by RS are the early events in atherosclerotic lesion formation (Stocker and Keaney 2004; Vogiatzi et al. 2009; Salvayre et al. 2002) Mostly macrophages are thought to be the source of reactive oxygen species (ROS) formation in the vessel wall but also other cells like endothelial, smooth muscle, and adventitial cells produce ROS in the vessel wall (Fortuno et al. 2005). In this direction, ox-LDL modulates atherosclerosis biology by cell damage induction, proliferation of smooth muscle cells, foam cell formation, chemotaxis of leukocytes, and secretion of inflammatory mediators. Since oxidation of LDL is the main oxidative modification, high plasma levels of native LDL is a risk factor for the progression (Stocker and Keaney 2004; Vogiatzi et al. 2009).

A growing body of evidence supports the notion that lipid rafts play a crucial role in the redox signaling that regulates the pathophysiology of many degenerative diseases. It is also known that distinct cholesterol- and sphingolipid-rich membrane rafts are importantly involved in transmembrane signaling in a variety of mammalian cells (Catalgol and Özer 2010; Das 2010).

Oxidative stress is closely associated with the neuropathology of $\mathrm{AD}$, a major neurodegenerative disorder characterized by multiple neurological events, gradual decline in cognitive functions, and rapid aging of the brain tissue. The major alterations in this disease are senile plaques (SP) and neurofibrillary tangles (NFT) represent an accumulation of intraneuronal and extracellular filamentous protein aggregates. Major proteins in these formations are hyperphosphorylated tau in NFT and amyloid beta $(\mathrm{A} \beta)$ peptide derived from amyloid precursor protein for SP (Markesbery and Lovell 2007). These protein aggregate formations in Alzheimer's disease cause the researchers to focus on the role of oxidative stress mainly protein oxidation in the process. The oxidative damage found in Alzheimer's disease includes advanced glycation end products (Smith et al. 1994; Ledesma et al. 1994), nitration (Good et al. 1996), lipid peroxidation adduction products (Salvayre et al. 2002; Montine et al. 1996), carbonyl modified neurofilament protein, and free carbonyls (Smith et al. 1991; Smith et al. 1995). Oxidized proteins (protein carbonyls) were found to be increased in frontal pole and occipital pole in Alzheimer's disease patients compared with controls (Sayre et al. 1997). Mishto et al. (Mishto et al. 2006) found a decrease in trypsin-like activity of proteasome emerged in hippocampus and cerebullum of Alzheimer's disease patients. In a study of Alzheimer's disease subjects compared with control groups, there was a significant increase in mitochondrial DNA oxidation in parietal cortex (Mecocci et al. 1994). Lovell et al. (Lovell et al. 1997) found elevated levels of free and protein-bound HNE in ventricular fluids of Alzheimer's disease patients. Iron in a redox-active state, thought to play an important role in free radical production in Alzheimer's disease, was shown to be increased in NFT as well as A $\beta$ deposits (Good et al. 1992). Iron catalyzes the formation of hydroxyl radical from $\mathrm{H}_{2} \mathrm{O}_{2}$ and also the formation of advanced glycation end products. $\mathrm{A} \beta$ itself has been directly implicated in ROS formation through peptidyl radicals (Hensley et al. 1994). Additionally, advanced glycation end products and $\mathrm{A} \beta$, activatespecific receptors, such as the receptor for advanced glycation end products (RAGE) and the class A scavengerreceptor, to increase reactive oxygen production (Yan et al. 1996).

Genetic factors (apolipoprotein E $\varepsilon 4$ allele), germline mutations (amyloid- $\beta$ protein precursor gene, presenilin-1 gene, and presenilin-2 gene), environmental causes, lifestyle-related factors (smoking), and certain health conditions such as diabetes, brain injury, and hypercholesterolemia cause oxidative stress in AD patients (Nunomura et al. 2006). Oxidative stress affects proteins (Hensley et al. 1998), nucleic acids (Smith et al. 1991), lipids (Sayre et al. 1997; 
Pratico et al. 2001; Schuessel et al. 2005), and enzymes (Premkumar et al. 1995) in AD patients. Increased nitrative stress in human $\mathrm{AD}$ brains has been reported in the form of increased levels of protein oxidation (Hensley et al. 1995), protein nitration (Keller et al. 2005), 3-nitrotyrosine, 3,3'dityrosine in hippocampus, and major regions of the brain including inferior parietal lobule, neocortical regions, and ventricular cerebrospinal fluid (Hensley et al. 1998). Both nuclear and mitochondrial DNA has been modified by oxidative stress to increased levels of 8-hydroxy-2-deoxyguanosine and oxidized bases in cerebral cortex and cerebellum of $\mathrm{AD}$ patients as compared with age-matched control subjects (Mishto et al. 2006; Wang et al. 2005). Increased levels of malondialdehyde, a measure of lipid peroxidation, are found in human AD brains (Balazs and Leon 1994). Numerous cellular and animal models of AD have been developed and considerable efforts have been taken to identify mechanisms of redox state-mediated gene regulation in relation to $\mathrm{AD}$ pathology.

Hypercholesterolemia is a major risk for coronary artery diseases. In the development of atherosclerosis, ROS are produced by endothelial cells, smooth muscle cells, and macrophages oxidize LDL in the subendothelial space, at the sites of endothelial damage, initiating events that culminate in the formation of a fibrous plaque. Rupture of fibrous plaque leads to thrombus formation and occlusion of the vessel (Stokes et al. 2002; Madamanchi et al. 2005). Prasad et al. (Prasad et al. 1997) showed that cholesterol feeding of rabbits caused an increase in MDA levels and glutathione peroxidase activities and a decrease in superoxide dismutase activity in the myocardium. Patients with elevated cholesterol may have increased susceptibility to $\mathrm{AD}$ in addition to coronary artery disease and hypertension (Pappolla et al. 2003). Cholesterol may initiate $\mathrm{A} \beta$ formation, which mentioned as a potent source of oxidative stress and irreversible protein aggregation. In one of our studies, to show the possible role of high cholesterol in AD, rabbits were fed with high cholesterol and following the increase in the serum cholesterol levels, MDA levels were shown to be increased consistent with the previous results (Aytan et al. 2008; Ozer et al. 2006; Ozer et al. 1998). Additionally, slight increase in HNE-proteins, 3-nitrotyrosinated proteins, and protein carbonyls was observed in hippocampus area of the rabbits. Proliferation of smooth muscle cells that migrate from arterial media into the subendothelial space is a central event in the onset of atherosclerosis both in humans and in animals. Ex vivo smooth muscle cells obtained from the aorta of cholesterolfed rabbits exhibited a twofold increase in protein kinase $\mathrm{C}$ (PKC) expression and activity (Sirikci et al. 1996).

Key components in atherogenesis including signaling molecules such as redox sensitive transcription factor $\mathrm{NF} \kappa \mathrm{B}$ activation and adhesion molecules such as selectins, vascular cell adhesion molecule-1 (VCAM-1), and intercellular adhesion molecule-1 (ICAM-1) and chemokines such as monocyte chemoattractant protein-1 (MCP-1) expressions in the vascular endothelium are known to be increased by RS. Expression of adhesion molecules and MCP-1 are also key steps for the monocyte adhesion and emigration to form macrophages and foam cells. Macrophage colony-stimulating factor (M-CSF) is an important factor regulating the survival, proliferation, differentiation, and chemotaxis of macrophages (Harizi and Gualde 2006; Pixley and Stanley 2004; Chitu and Stanley 2006; Fan and Watanabe 2003). The effects of ox-LDL on NF $\kappa$ B may be biphasic as concentration dependent. Normally, it activates $\mathrm{NF} \kappa \mathrm{B}$ and upregulates the expressions of adhesion molecules, tissue factor, and LOX-1. In high concentration, oxLDL inhibits $\mathrm{NF} \kappa \mathrm{B}$ activation triggered by inflammatory agents such as lipoxygenases and therefore exert immunosupressive effect (Robbesyn et al. 2004). HNEs were shown to activate MAPK in endothelial cells either by directly interacting with PKC or through activation of the EGF receptor (Uchida et al. 1999).

The presence of foam cells in the atherosclerosis process confirms the importance of CD36 scavenger receptors. CD36 has an important role in the intake of ox-LDL by macrophages in the arteria walls and long-chain fatty acids into the cells. Following binding of ox-LDL to CD36 receptor, lyn kinase, a src protein tyrosine kinase, is activated. This activation induces mitogen ERK kinase kinase 2 (MEKK2) and c-jun N-terminal kinase (JNK) activation and phagocytosis of proatherogenic ox-LDL (Rahaman et al. 2006). CD36 was shown to be upregulated by PKC and PPAR $\gamma$ pathway which are common signaling mechanisms for IL4 and ox-LDL (Feng et al. 2000). CD36 scavenger receptor expression was shown to be increased in ox-LDL treated aortic smooth muscle cells in culture (Ricciarelli et al. 2000). It has been shown as in vivo that hypercholesterolemia increases foam cell formation and atherosclerosis by increasing CD36 mRNA expression and PKC activity in rabbits (Ozer et al. 2006; Ozer et al. 1998; Sirikci et al. 1996).

\section{Vitamin E: from an antioxidant to a signaling molecule}

Vitamin E was discovered in 1922 in green leafy vegetables by University of California researchers, Herbert Evans, and Katherine Bishop. Two decades after the "biological antioxidant theory" (Green and Bunyan 1969) was reported, and Burton and Ingold presented the first comprehensive review article discussing that $\alpha$-tocopherol has near optimal activity as a chain-breaking antioxidant and that both the phenolic head and phytyl tails contributed to the biological properties of the vitamin $\mathrm{E}$ molecule 
(Burton and Ingold 1989). In recent studies, vitamin E term includes eight naturally occurring components including the respective $\alpha, \beta, \gamma$, and $\delta$ derivatives of tocopherol and tocotrienol. Among them, RRR- $\alpha$-tocopherol is by far the most abundant lipid-soluble antioxidant in humans and it is present in cellular and sub-cellular membranes (Cordero et al. 2010). Besides this, tocotrienols were shown to possess powerful neuroprotective, anti-cancer, and cholesterol lowering properties (Sen et al. 2006).

Vitamin E emerged as an essential, fat soluble nutrient that functions as an antioxidant in the human body. It is essential, because the body cannot manufacture its own vitamin $\mathrm{E}$ and foods and supplements must provide it. Vitamin E represents one of the most fascinating natural resources that have the potential to influence a broad range of mechanisms underlying human health and disease. There are many studies carried out to gain insight into the effects of Vitamin E components, especially tocotrienol, on the several age-related diseases. In hypercholesterolemic human subjects tocotrienol lowered serum cholesterol (Qureshi et al. 1991), lowered both serum total cholesterol, and low-density-lipoprotein cholesterol (Tan et al. 1991), regulated cholesterol production in mammalian cells by post-transcriptional suppression of 3-hydroxy-3-methylglutarylcoenzyme A reductase (Parker et al. 1993), lowered plasma cholesterol level in hypercholesterolemic subjects (Qureshi et al. 1995), tocotrienol-rich fraction of rice bran suppressed serum cholesterol dose-dependently (Qureshi et al. 2002). Qureshi et al. (2001) claimed that in hypercholesterolemic humans, tocotrienol is converted to tocopherol in vivo. In another human study, dietary tocotrienols were shown to be incorporated into circulating human lipoproteins where they react with peroxyl radicals as efficiently as the corresponding tocopherol isomers (Suarna et al. 1993). Palm tocotrienols was shown to protect $\mathrm{ApoE} \pm$ mice from diet-induced atheroma formation (Black et al. 2000) and tocotrienols was shown to inhibit atherosclerotic lesions in ApoE-deficient mice (Qureshi et al. 2001). It is thought that the unsaturated side chain of tocotrienol allows for more efficient penetration into tissues that have saturated fatty layers such as the brain and liver (Suzuki et al. 1993). Also tocotrienol administration reduced oxidative protein damage and extended the mean life span of C. elegans (Adachi and Ishii 2000).

$\alpha$-Tocopherol was identified as the major antioxidant present in human lipoproteins, it received much attention as a suppressor of LDL lipid oxidation and as an epidemiological marker for ischemic heart disease. At the posttranslational level, $\alpha$-tocopherol was shown to inhibit protein kinase C, 5-lipoxygenase and phospholipase A2 and activate protein phosphatase $2 \mathrm{~A}$ and diacylglycerol kinase (Sen et al. 2006). The mechanism of PKC regulation by $\alpha$-tocopherol has been investigated in smooth muscle cells. Treatment of rat aortic A7r5 smooth muscle cells with $\alpha$-tocopherol resulted in a time- and dose-dependent inhibition of PKC. Autophosphorylation and kinase activities of the different isoforms have shown that only $\mathrm{PKC} \alpha$ was inhibited by $\alpha$-tocopherol. The inhibitory effects were not mimicked by $\beta$-tocopherol, an analog of $\alpha$-tocopherol with similar antioxidant properties (Ricciarelli et al. 1998). The role of $\mathrm{d}$ - $\alpha$-tocopherol in the proliferation and protein kinase $\mathrm{C}$ activity of smooth muscle cells promoted by native and malondialdehyde-modified LDL was also investigated. The data showed that $d-\alpha$-tocopherol inhibits vascular smooth muscle cell proliferation and protein kinase $\mathrm{C}$ activation produced by both types of LDL (Ozer et al. 1993).

Some genes (e.g., scavenger receptors, $\alpha$-TTP, $\alpha$-tropomyosin, matrix metalloproteinase-19, and collagenase) are specifically modulated by $\alpha$-tocopherol at the transcriptional level. $\alpha$-Tocopherol also inhibits cell proliferation, platelet aggregation and monocyte adhesion. These effects have been characterized to be unrelated to the antioxidant activity of vitamin $\mathrm{E}$ and possibly reflect specific interactions of $\alpha$-tocopherol with enzymes, structural proteins, lipids, and transcription factors (Zingg and Azzi 2004). The role of Vitamin E on CD36 expression in an in vivo model was tested. Atherosclerosis was induced by a $2 \%$ cholesterol containing Vitamin E poor diet. Three groups of six rabbits each were studied. The first group (control) was fed on Vitamin E poor diet. The second group was fed with Vitamin E poor diet containing $2 \%$ cholesterol, and the rabbits in the third group were fed with Vitamin E poor diet containing $2 \%$ cholesterol and received injections of $50 \mathrm{mg} / \mathrm{kg}$ of Vitamin E i.m. After 4 weeks, aortas were removed and analyzed by light microscopy for atherosclerotic lesions. Aortic samples were analyzed for CD36 mRNA expression. The aortas of cholesterol-fed rabbits showed typical atherosclerotic lesions, detected by macroscopic and microscopic examination, and exhibited an increase in CD36 mRNA expression. Vitamin $\mathrm{E}$ fully prevented cholesterol-induced atherosclerotic lesions and the induction of CD36 mRNA expression. The effects observed at the level of CD36 scavenger receptor expression in vivo suggest an involvement of reduced foam cell formation in the protective effect of Vitamin $\mathrm{E}$ against atherosclerosis (Ozer et al. 2006).

The effect of tocopheryl phosphate on atherosclerosis progression has been studied in rabbits, fed with a $2 \%$ cholesterol diet and compared with an equivalent amount of $\alpha$-tocopheryl acetate. The results show that the atherosclerosis preventing effect of the phosphate derivative was more pronounced than that of the acetate derivative. $\alpha$-Tocopheryl phosphate was also more potent in diminishing the expression of CD36 than the acetate derivative (Negis et al. 2006). 
The possible role of vitamin $\mathrm{E}$ on the cardiovascular diseases was initially proposed in the so-called "antioxidant hypothesis of atherosclerosis" (Gey 1995). On the other hand, vitamin E may as well exhibit pro-oxidative activity under specific conditions, possibly leading to tocopherol-mediated lipid peroxidation (Thomas et al. 1995; Upston et al. 1999). Other research investigations have reported evidence on alternative functions of vitamin $\mathrm{E}$ on atherosclerosis beyond its antioxidant role such as anti-inflammatory functions, regulation of the expression of genes involved in growth, apoptosis and inflammation, modulation of the immune response, and detoxification of xenobiotics (Azzi et al. 1995; Kaul et al. 2001; Ricciarelli et al. 2001; Traber and Atkinson 2007).

The association between vitamin $\mathrm{E}$ intake from food and/or supplements and cardiovascular disease (myocardial infarction and/or stroke) events (fatal and/or non-fatal) has been analyzed by the following nine prospective cohort studies: Health Professionals Follow-up Study (HPFS) (Rimm et al. 1993; Ascherio et al. 1999), Iowa Women's Health Study (IWHS) (Kushi et al. 1996; Yochum et al. 2000), Scottish Heart Health Study (SHHS) (Todd et al. 1999), Cancer Prevention Study II (CPS-II) (Watkins et al. 2000), Physician Health Study (PS) (Muntwyler et al. 2002), Nurses' Health Study (NHS) (Stampfer et al. 1993), Finnish Cohort Study (FS) (Knekt et al. 1994), The Zutphen Study (ZS) (Bocan et al. 1993), and one analyses from the Alpha-Tocopherol, Beta-Carotene Cancer Prevention Study (ATBC) (Smith 1974). These studies reported a $5 \%$ reduction of coronary heart disease risk among men from dietary vitamin E intake (SHHS) (Todd et al. 1999), a 32\% reduction of coronary heart disease risk among men from dietary vitamin $\mathrm{E}$ intake (FS) (Knekt et al. 1994), a $40 \%$ reduction of coronary heart disease risk among men from dietary and supplemental vitamin $\mathrm{E}$ intake (HPFS) (Rimm et al. 1993), a 34\% reduction of major coronary heart disease risk among women from dietary and supplemental vitamin $\mathrm{E}$ intake (NHS) (Stampfer et al. 1993), a 62\% reduction of coronary heart disease risk among women from dietary vitamin $\mathrm{E}$ intake (IWSS) (Kushi et al. 1996), a 65\% reduction of coronary heart disease risk among women from dietary vitamin $\mathrm{E}$ intake (FS) (Knekt et al. 1994), a 10-14\% reduction of ischemic heart disease risk among women users of vitamin $\mathrm{E}$, vitamin $\mathrm{C}$, and/or vitamin A without multivitamins or plus multivitamins (CPS-II) (Watkins et al. 2000), and a $59 \%$ reduction of coronary heart disease mortality among men who took vitamin $\mathrm{E}$ supplements for more than 4 years (a secondary analysis within PS) (Muntwyler et al. 2002). A total of four analyses addressed the relationship between the vitamin $\mathrm{E}$ intake and stroke events with a $60 \%$ reduced stroke mortality associated with higher dietary vitamin E intake within the IWHS (Yochum et al. 2000) and a $15 \%$ reduced stroke incidence among women who took vitamin E-containing multivitamins for more than 5 years within the CPS-II (Watkins et al. 2000). In contrast, supplementation with vitamin $\mathrm{E}$ had no effect on cardiovascular disease incidence in most of the randomized control trials conducted so far. In our animal studies, the rabbits were made atherosclerotic by using a cholesterolrich diet, commonly used to produce atherosclerosis (Aytan et al. 2008; Ozer et al. 2006; Ozer et al. 1998; Sirikci et al. 1996). A high cholesterol supplementation was preferred to lower cholesterol containing diets. This decision turned out to have the advantage of maximizing the atherosclerotic result and diminishing the treatment time. Although some studies reported (Bocan et al. 1993; Smith 1974; Guyton et al. 1985), diminution of plasma cholesterol associated with vitamin E supplementation was not visible under these conditions. However, the very high cholesterol supplementation may also be the reason for the lack of a statistically significant effect of vitamin $\mathrm{E}$.

The majority of the age-related diseases has increased the preclinical evaluation of putative antioxidant agents ranging from prototypic natural antioxidants such as vita$\min \mathrm{E}(\boldsymbol{\alpha}$-tocopherol) to sophisticated synthetic free radical traps and catalytic oxidants. In spite of scientific evidence supporting oxidative stress as a pathogenic factor in agerelated diseases, human clinical trials with antioxidant protectants has been generally negative (Keli et al. 1996; Hirvonen et al. 2000; Kamat et al. 2008) although some vitamin $\mathrm{E}$ experiments in $\mathrm{AD}$ showed a positive effect on quality-of-life parameters, such as time to enter a nursing facility (Sano et al. 1997).

Vitamin $\mathrm{E}$ is an archetype micronutrient which has been able to reach sub-therapeutic levels in brains of $\mathrm{AD}$ patients and decrease lipid peroxidation susceptibility by $60 \%$ in $\mathrm{AD}$ patients as compared with control subjects (Galbusera et al. 2004; Veinbergs et al. 2000). Vitamin E has been frequently tested in epidemiologic and clinical studies for AD and cognitive disorders. The data from these trials are available for symptomatic treatments (Sano et al. 1997; Cash et al. 2002) as well as preventive therapies for AD (Nunomura et al. 2006). Some of the clinical trials for vitamin $\mathrm{E}$, alone or in combination with vitamin $\mathrm{C}$, against cognitive disorders showed positive effects for vitamin $\mathrm{E}$; e.g., Honolulu-Asia Aging study (3,385 men) (Masaki et al. 2000); Chicago Health and Aging Project (815 subjects; 3.9 years follow-up study) and Nurses' Health Study (14,986 women aged 70-79 years) (Grodstein et al. 2003) whereas, some studies showed contrasting effects for vitamin E (Petersen et al. 2005), which include HonoluluAsia Aging study (2,459 men; Vitamin E alone) (Petersen et al. 2005; Laurin et al. 2004; Luchsinger et al. 2003), Washington Heights Study (980 subjects; 4 year follow-up study), and Cache Country Study (4,740 subjects; 3 years 
follow-up study) (Zandi et al. 2004). Many of the above studies focused on vitamin $\mathrm{E}$ and $\mathrm{C}$ supplements alone or in combination with each other or other supplements. Among the different preventive and therapeutic strategies dietary $\alpha$-tocopherol supplementation has been shown in some studies to exert positive effects in the brain (Sano et al. 1997; Morris et al. 2002).

\section{Conclusion}

There is a large body of evidence connecting the effects of oxidative stress and related signaling mechanisms with hypercholesterolemia-induced age-related diseases. The majority of these diseases in the aging and the role of oxidative stress-related changes in the progress pushed researchers to focus on the investigation of removal and repair mechanisms for the balance of oxidative stress. Vitamin E components took the main place in these investigations and thought to bring hopeful results in the clinical applications.

Acknowledgments The author wishes to acknowledge the support of the COSTB35 Action; TUBITAK SBAG-COSTB35-5(106S121), MU BABKO-SAG-DKR-290506-0091; MU BABKO SAG-C-YLP050608-0125.

\section{References}

Adachi H, Ishii N (2000) Effects of tocotrienols on life span and protein carbonylation in Caenorhabditis elegans. J Gerontol A 55(6):B280-B285

Ascherio A, Rimm E, Hernan MA, Giovannucci E, Kawachi I, Stampfer MJ et al (1999) Relation of consumption of vitamin E, vitamin $\mathrm{C}$, and carotenoids to risk for stroke among men in the United States. Ann Intern Med 130(12):963-970

Aytan N, Jung T, Tamturk F, Grune T, Kartal Ozer N (2008) Oxidative stress related changes in the brain of hypercholesterolemic rabbits. Biofactors 33:225-236

Azzi A, Boscoboinik D, Marilley D, Ozer NK, Stauble B, Tasinato A (1995) Vitamin E: a sensor and an information transducer of the cell oxidation state. Am J Clin Nutr 62(6 Suppl):1337S-1346S

Balazs L, Leon M (1994) Evidence of an oxidative challenge in the Alzheimer's brain. Neurochem Res 19:1131-1137

Black TM, Wang P, Maeda N, Coleman RA (2000) Palm tocotrienols protect ApoE \pm mice from diet-induced atheroma formation. J Nutr 130(10):2420-2426

Bocan TM, Mueller SB, Mazur MJ, Uhlendorf PD, Brown EQ, Kieft KA (1993) The relationship between the degree of dietaryinduced hypercholesterolemia in the rabbit and atherosclerotic lesion formation. Atherosclerosis 102:9-22

Burton GW, Ingold KU (1989) Vitamin E as an in vitro and in vivo antioxidant. Ann N Y Acad Sci 570:7-22

Butterfield DA, Martin L, Carney JM, Hensley K (1996) A beta (25-35) peptide displays $\mathrm{H}_{2} \mathrm{O}_{2}$-like reactivity towards aqueous $\mathrm{Fe}^{2+}$, nitroxide spin probes, and synaptosomal membrane proteins. Life Sci 58:217-228

Cash AD, Perry G, Smith MA (2002) Therapeutic potential in Alzheimer disease. Curr Med Chem 9:1605-1610
Catalgol B, Grune T (2009) Protein pool maintenance during oxidative stress. Curr Pharm Des 15(26):3043-3051

Catalgol B, Özer NK (2010) Lipid rafts and redox regulation of cellular signaling in cholesterol induced atherosclerosis. Curr Cardiol Rev 6(4):309-324

Chitu V, Stanley ER (2006) Colony-stimulating factor-1 in immunity and inflammation. Curr Opin Immunol 18:39-48

Cordero Z, Drogan D, Weikert C, Boeing H (2010) Vitamin E and risk of cardiovascular diseases: a review of epidemiologic and clinical trial studies. Crit Rev Food Sci Nutr 50(5):420-440

Das DK (2010) Redox signaling via lipid rafts. In: Dipak Das (ed) Methods in redox signaling. Mary Ann Liebert, p 156-158

Fan J, Watanabe T (2003) Inflammatory reactions in the pathogenesis of atherosclerosis. J Atheroscler Thromb 10:63-71

Feng J, Han J, Pearce SFA, Silverstein RL, Gotto AM, Hajjar DP et al (2000) Induction of CD36 expression by oxidized LDL and IL-4 by a common signaling pathway dependent on protein kinase $\mathrm{C}$ and PPAR-gamma. J Lipid Res 41:688-696

Fortuno A, Jose GS, Moreno MU, Diez J, Zalba G (2005) Oxidative stress and vascular remodelling. Exp Physiol 90:457-462

Francis PT, Palmer AM, Snape M, Wilcock GK (1999) The cholinergic hypothesis of Alzheimer's disease: a review of progress. J Neurol Neurosurg Psychiat 66:137-147

Galbusera C, Facheris M, Magni F, Galimberti G, Sala G, Tremolada L et al (2004) Increased susceptibility to plasma lipid peroxidation in Alzheimer disease patients. Curr Alzheimer Res 1:103-109

Gey KF (1995) Ten-year retrospective on the antioxidant hypothesis of arteriosclerosis: Threshold plasma levels of antioxidant micronutrients related to minimum cardiovascular risk. J Nutr Biochem 6:206-236

Good PF, Perl DP, Bierer LM, Schmeidler J (1992) Selective accumulation of aluminum and iron in the neurofibrillary tangles of Alzheimer's disease: a laser microprobe (LAMMA) study. Ann Neurol 31(3):286-292

Good PF, Werner P, Hsu A, Olanow CW, Perl DP (1996) Evidence of neuronal oxidative damage in Alzheimer's disease. Am J Pathol 149(1):21-28

Green J, Bunyan J (1969) Vitamin E and the biological antioxidant theory. Nutr Abst Rev 39(2):321-345

Griffiths HR, Moller L, Bartosz G, Bast A, Bertoni-Freddari C, Collins A, Cooke M, Coolen S, Haenen G, Hoberg AM, Loft S, Lunec J, Olinski R, Parry J, Pompella A, Poulsen H, Verhagen H, Astley SB (2002) Biomarkers. Mol Aspects Med 23(1-3):101-208

Grodstein F, Chen J, Willett WC (2003) High-dose antioxidant supplements and cognitive function in community-dwelling elderly women. Am J Clin Nutr 77:975-984

Guyton JR, Bocan TM, Schifani TA (1985) Quantitative ultrastructural analysis of perifibrous lipid and its association with elastin in nonatherosclerotic human aorta. Arteriosclerosis 5:644-652

Harizi H, Gualde N (2006) Pivotal role of PGE2 and IL-10 in the cross-regulation of dendritic cell-derived inflammatory mediators. Cell Mol Immunol 3:271-277

Hensley K, Carney JM, Mattson MP, Aksenova M, Harris M, Wu JF et al (1994) A model for beta-amyloid aggregation and neurotoxicity based on free radical generation by the peptide: relevance to Alzheimer disease. Proc Natl Acad Sci USA 91(8):3270-3274

Hensley K, Hall N, Subramaniam R, Cole P, Harris M, Aksenov M et al (1995) Brain regional correspondence between Alzheimer's disease histopathology and biomarkers of protein oxidation. J Neurochem 65:2146-2156

Hensley K, Maidt ML, Yu Z, Sang H, Markesbery WR, Floyd RA (1998) Electrochemical analysis of protein nitrotyrosine and dityrosine in the Alzheimer brain indicates region-specific accumulation. J Neurosci 18:8126-8132 
Hirvonen T, Virtamo J, Korhonen P, Albanes D, Pietinen P (2000) Intake of flavonoids, carotenoids, vitamins $\mathrm{C}$ and $\mathrm{E}$, and risk of stroke in male smokers. Stroke 31(10):2301-2306

Kamat CD, Gadal S, Mhatre M, Williamson KS, Pye QN, Hensley K (2008) Antioxidants in central nervous system diseases: preclinical promise and translational challenges. J Alzheimers Dis 15(3):473-493

Kaul N, Devaraj S, Jialal I (2001) Alpha-tocopherol and atherosclerosis. Exp Biol Med 226:5-12

Keli SO, Hertog M, Feskens EJ, Kromhout D (1996) Dietary flavonoids, antioxidant vitamins, and incidence of stroke: the Zutphen study. Arch Intern Med 156(6):637-642

Keller JN, Schmitt FA, Scheff SW, Ding Q, Chen Q, Butterfield DA et al (2005) Evidence of increased oxidative damage in subjects with mild cognitive impairment. Neurology 64:1152-1156

Knekt P, Reunanen A, Jarvinen R, Seppanen R, Heliovaara M, Aromaa A (1994) Antioxidant vitamin intake and coronary mortality in a longitudinal population study. Am J Epidemiol 139(12):1180-1189

Kushi LH, Folsom A, Prineas RJ, Mink PJ, Wu Y, Bostick RM (1996) Dietary antioxidant vitamins and death from coronary heart disease in postmenopausal women. N Engl J Med 334(18): 1156-1162

Laurin D, Masaki KH, Foley DJ, White LR, Launer LJ (2004) Midlife dietary intake of antioxidants and risk of late-life incident dementia: the Honolulu-Asia aging study. Am J Epidemiol 159:959-967

Ledesma MD, Bonay P, Colaco C, Avila J (1994) Analysis of microtubule-associated protein tau glycation in paired helical filaments. J Biol Chem 269(34):21614-21619

Lovell MA, Ehmann WD, Markesbery WR (1997) Elevated 4-hydroxynonenal in ventricular fluid in alzheimer's disease. Neurobiol Aging 18(5):457-461

Luchsinger JA, Tang MX, Shea S, Mayeux R (2003) Antioxidant vitamin intake and risk of Alzheimer disease. Arch Neurol 60:203-208

Madamanchi NR, Vendrov A, Runge MS (2005) Oxidative stress and vascular disease. Arterioscler Thromb Vasc Biol 25(1):29-38

Markesbery WR, Lovell MA (2007) Damage to lipids, proteins, DNA, and RNA in mild cognitive impairment. Arch Neurol 64: 954-956

Masaki KH, Losonczy KG, Izmirlian G, Foley DJ, Ross GW, Petrovitch $\mathrm{H}$ et al (2000) Association of vitamin E and C supplement use with cognitive function and dementia in elderly men. Neurology 54:1265-1272

Masliah E, Alford M, DeTeresa R, Mallory M, Hansen L (1996) Deficient glutamate transport is associated with neurodegeneration in Alzheimer's disease. Ann Neurol 40:759-766

Mecocci P, MacGarvey U, Beal MF (1994) Oxidative damage to mitochondrial DNA is increased in alzheimer's disease. Ann Neurol 36:747-751

Mishto M, Belavista E, Santoro A, Stolzing A, Ligorio C, Nacmias B et al (2006) Immunoproteasome and LMP2 polymorphism in aged and alzheimer's disease brains. Neurobiol Aging 27:54-66

Montine TJ, Amarnath V, Martin ME, Strittmatter WJ, Graham DG (1996) E-4-hydroxy-2-nonenal is cytotoxic and cross-links cytoskeletal proteins in P19 neuroglial cultures. Am J Pathol 148(1):89-93

Morris MC, Evans DA, Bienias JL, Tangney CC, Bennett DA, Aggarwal N, Wilson RS, Scherr PA (2002) Dietary intake of antioxidant nutrients and the risk of incident Alzheimer disease in a biracial community study. JAMA 287:3230-3237

Muntwyler J, Hennekens CH, Manson JE, Buring JE, Gaziano JM (2002) Vitamin supplement use in a low-risk population of US male physicians and subsequent cardiovascular mortality. Arch Intern Med 162(13):1472-1476
Negis Y, Aytan N, Ozer N, Ogru E, Libinaki R, Gianello R et al (2006) The effect of tocopheryl phosphates on atherosclerosis progression in rabbits fed with a high cholesterol diet. Arch Biochem Biophys 450(1):63-66

Nordberg J, Arnér ES (2001) Reactive oxygen species, antioxidants, and the mammalian thioredoxin system. Free Radic Biol Med 31(11):1287-1312

Nunomura A, Castellani RJ, Zhu X, Moreira PI, Perry G, Smith MA (2006) Involvement of oxidative stres in Alzheimer disease. J Neuropathol Exp Neurol 65:631-641

Osterud B, Bjorklid E (2003) Role of monocytes in atherogenesis. Physiol Rev 83(4):1069-1112

Ozer NK, Palozza P, Boscoboinik D, Azzi A (1993) d-alphatocopherol inhibits low density lipoprotein induced proliferation and protein kinase $\mathrm{C}$ activity in vascular smooth muscle cells. FEBS Lett 322(3):307-310

Ozer NK, Sirikci O, Taha S, San T, Moser U, Azzi A (1998) Effect of vitamin $\mathrm{E}$ and probucol on dietary cholesterol-induced atherosclerosis in rabbits. Free Radic Biol Med 24(2):226-233

Ozer NK, Negis Y, Aytan N, Villacorta L, Ricciarelli R, Zingg JM et al (2006) Vitamin E inhibits CD36 scavenger receptor expression in hypercholesterolemic rabbits. Atherosclerosis 184(1):15-20

Pappolla MA, Bryant-Thomas TK, Herbert D, Pacheco J, Fabra Garcia M, Manjon M et al (2003) Mild hypercholesterolemia is an early risk factor for the development of Alzheimer amyloid pathology. Neurology 61(2):199-205

Parker RA, Pearce BC, Clark RW, Gordon DA, Wright JJ (1993) Tocotrienols regulate cholesterol production in mammalian cells by post-transcriptional suppression of 3-hydroxy-3-methylglutarylcoenzyme A reductase. J Biol Chem 268(15):11230-11238

Petersen RC, Thomas RG, Grundman M, Bennett D, Doody R, Ferris $S$ et al (2005) Vitamin $E$ and donepezil for the treatment of mild cognitive impairment. N Engl J Med 352:2379-2388

Pixley FJ, Stanley ER (2004) CSF-1 regulation of the wandering macrophage: complexity in action. Trends Cell Biol 14:628-638

Prasad K, Mantha S, Kalra J, Lee P (1997) Hypercholesterolemiainduced oxidative stress in heart and its prevention by vitamin $\mathrm{E}$. Int J Angiol 6:13-17

Pratico D, Uryu K, Leight S, Trojanoswki JQ, Lee VM (2001) Increased lipid peroxidation precedes amyloid plaque formation in an animal model of Alzheimer amyloidosis. J Neurosci 21: $4183-4187$

Premkumar DR, Smith MA, Richey PL, Petersen RB, Castellani R, Kutty RK et al (1995) Induction of heme oxygenase-1 mRNA and protein in neocortex and cerebral vessels in Alzheimer's disease. J Neurochem 65:1399-1402

Qureshi AA, Qureshi N, Wright JJ, Shen Z, Kramer G, Gapor A et al (1991) Lowering of serum cholesterol in hypercholesterolemic humans by tocotrienols (palmvitee). Am J Clin Nutr 53(4 Suppl):1021S-1026S

Qureshi AA, Bradlow BA, Brace L, Manganello J, Peterson DM, Pearce BC et al (1995) Response of hypercholesterolemic subjects to administration of tocotrienols. Lipids 30(12): 1171-1177

Qureshi AA, Sami SA, Salser WA, Khan FA (2001a) Synergistic effect of tocotrienol-rich fraction $(\mathrm{TRF}(25))$ of rice bran and lovastatin on lipid parameters in hypercholesterolemic humans. J Nutr Biochem 12(6):318-329

Qureshi AA, Salser WA, Parmar R, Emeson EE (2001b) Novel tocotrienols of rice bran inhibit atherosclerotic lesions in C57BL/ 6 ApoE-deficient mice. J Nutr 131(10):2606-2618

Qureshi AA, Sami SA, Salser WA, Khan FA (2002) Dose-dependent suppression of serum cholesterol by tocotrienol-rich fraction (TRF25) of rice bran in hypercholesterolemic humans. Atherosclerosis 161(1):199-207 
Rahaman SO, Lennon DJ, Febbraio M, Podrez EA, Hazen SL, Silverstein RL (2006) A CD36-dependent signaling cascade is necessary for macrophage foam cell formation. Cell Metab 4:211-221

Ricciarelli R, Tasinato A, Clément S, Ozer NK, Boscoboinik D, Azzi A (1998) Alpha-tocopherol specifically inactivates cellular protein kinase $\mathrm{C}$ alpha by changing its phosphorylation state. Biochem J 334(Pt 1):243-249

Ricciarelli R, Zingg JM, Azzi A (2000) Vitamin E reduces the uptake of oxidized LDL by inhibiting CD36 scavenger receptor expression in cultured aortic smooth muscle cells. Circulation 102(1):82-87

Ricciarelli R, Zingg J, Azzi A (2001) Vitamin E: protective role of a Janus molecule. FASEB J 15(13):2314-2325

Rimm EB, Stampfer M, Ascherio A, Giovannucci E, Colditz GA, Willett WC (1993) Vitamin E consumption and the risk of coronary heart disease in men. N Engl J Med 328(20):1450-1456

Robbesyn F, Salvayre R, Negre-Salvayre A (2004) Dual role of oxidized LDL on the NF-kappaB signaling pathway. Free Radic Res 38(6):541-551

Salvayre R, Auge N, Benoist H, Negre-Salvayre A (2002) Oxidized low-density lipoprotein-induced apoptosis. Biochim Biophys Acta 1585(2-3):213-221

Sano M, Ernesto C, Thomas RG, Klauber MR, Schafer K, Grundman $\mathrm{M}$ et al (1997) A controlled trial of selegiline, alpha-tocopherol, or both as treatment for Alzheimer's disease. The Alzheimer's disease cooperative study. N Engl J Med 336:1216-1222

Sayre LM, Zelasko DA, Haris PL, Perry G, Salomon RG, Smith MA (1997) 4-Hydroxynonenal-derived advanced lipid peroxidation end products are increased in Alzheimer's disease. J Neurochem 68(5):2092-2097

Schmitz G, Grandl M (2007) Role of redox regulation and lipid rafts in macrophages during ox-LDL mediated foam cell formation. Antioxid Redox Signal 9(9):1499-1518

Schuessel K, Schafer S, Bayer TA, Czech C, Pradier L, Muller-Spahn $\mathrm{F}$ et al (2005) Impaired $\mathrm{Cu} / \mathrm{Zn}$ - SOD activity contributes to increased oxidative damage in APP transgenic mice. Neurobiol Dis 18:89-99

Sen CK, Khanna S, Roy S (2006) Tocotrienols: vitamin E beyond tocopherols. Life Sci 78:2088-2098

Sirikci O, Ozer NK, Azzi A (1996) Dietary cholesterol induced changes of protein kinase $\mathrm{C}$ and the effect of vitamin $\mathrm{E}$ in rabbit aortic smooth muscle cells. Atherosclerosis 126:253-263

Smith EB (1974) The relationship between plasma, tissue lipids in human atherosclerosis. Adv Lipid Res 12:1-49

Smith CD, Carney JM, Starke-Reed PE, Oliver CN, Stadtman ER, Floyd RA et al (1991) Excess brain protein oxidation and enzyme dysfunction in normal aging and in Alzheimer disease. Proc Natl Acad Sci USA 88(23):10540-10543

Smith MA, Taneda S, Richey PL, Miyata S, Yan SD, Stern D et al (1994) Advanced Maillard reaction end products are associated with Alzheimer disease pathology. Proc Natl Acad Sci USA 91(12):5710-5714

Smith MA, Rudnicka-Nawrot M, Richey PL, Praprotnik D, Mulvihill $\mathrm{P}$, Miller CA et al (1995) Carbonyl-related posttranslational modification of neurofilament protein in the neurofibrillary pathology of Alzheimer's disease. J Neurochem 64(6):26602666

Squier TC (2001) Oxidative stress and protein aggregation during biological aging. Exp Gerontol 36:1539-1550

Stampfer MJ, Hennenkens C, Manson JE, Colditz GA, Rosner B, Willett WC (1993) Vitamin E consumption and the risk of coronary disease in women. N Engl J Med 328(20):1444-1449

Steinberg D (2009) The LDL modification hypothesis of atherogenesis: an update. J Lipid Res 50:S376-S381
Stocker R, Keaney JF Jr (2004) Role of oxidative modifications in atherosclerosis. Physiol Rev 84(4):1381-1478

Stokes KY, Cooper D, Tailor A, Granger DN (2002) Hypercholesterolemia promotes inflammation and microvascular dysfunction: role of nitric oxide and superoxide. Free Radic Biol Med 33(8):1026-1036

Suarna C, Hood RL, Dean RT, Stocker R (1993) Comparative antioxidant activity of tocotrienols and other natural lipidsoluble antioxidants in a homogeneous system, and in rat and human lipoproteins. Biochim Biophys Acta 1166(2-3):163-170

Sultana R, Perluigi M, Butterfield DA (2006) Protein oxidation and lipid peroxidation in brain of subjects with Alzheimer's disease: insights into mechanism of neurode-generation from redox proteomics. Antioxid Redox Signal 8:2021-2037

Suzuki YJ, Tsuchiya M, Wassall SR, Choo YM, Govil G, Kagan VE et al (1993) Structural and dynamic membrane properties of alpha-tocopherol and alpha-tocotrienol: implication to the molecular mechanism of their antioxidant potency. Biochemistry 32(40):10692-10699

Tan DT, Khor HT, Low WH, Ali A, Gapor A (1991) Effect of a palmoil-vitamin E concentrate on the serum and lipoprotein lipids in humans. J Clin Nutr 53(4 Suppl):1027S-1030S

Thomas SR, Neuzil J, Mohr D, Stocker R (1995) Coantioxidants make alpha-tocopherol an efficient antioxidant for low-density lipoprotein. Am J Clin Nutr 62(6 Suppl):1357S-1364S

Todd S, Woodward M, Tunstall-Pedoe H, Bolton-Smith C (1999) Dietary antioxidant vitamins and fiber in the etiology of cardiovascular disease and all-causes mortality: results from the Scottish heart health study. Am J Epidemiol 150(10):1073-1080

Traber MG, Atkinson JM (2007) Vitamin E, antioxidant and nothing more. Free Radic Biol Med 43(1):4-15

Uchida K, Shiraishi M, Naito Y, Torii Y, Nakamura Y, Osawa T (1999) Activation of stress signaling pathways by the end product of lipid peroxidation. 4-hydroxy-2-nonenal is a potential inducer of intracellular peroxide production. J Biol Chem 274:2234-2242

Upston JM, Terentis A, Stocker R (1999) Tocopherol-mediated peroxidation of lipoproteins: implications for vitamin $\mathrm{E}$ as a potential antiatherogenic supplement. FASEB J 13(9):977-994

Veinbergs I, Mallory M, Sagara Y, Masliah E (2000) Vitamin E supplementation prevents spatial learning deficits and dendritic alterations in aged apolipoprotein E-deficient mice. Eur J Neurosci 12:4541-4546

Vogiatzi G, Tousoulis D, Stefanadis C (2009) The role of oxidative stress in atherosclerosis. Hellenic J Cardiol 50(5):402-409

Wang J, Xiong S, Xie C, Markesbery WR, Lovell MA (2005) Increased oxidative damage in nuclear and mitochondrial DNA in Alzheimer's disease. J Neurochem 93:953-962

Watkins ML, Erickson JD, Thun MJ, Mulinare J, Heath CW Jr (2000) Multivitamin use and mortality in a large prospective study. Am J Epidemiol 152(2):149-162

Yan SD, Chen X, Fu J, Chen M, Zhu H, Roher A, Slattery T, Zhao L, Nagashima M, Morser J, Migheli A, Nawroth P, Stern D, Schmidt AM (1996) RAGE and amyloid-beta peptide neurotoxicity in Alzheimer's disease. Nature 382(6593):685-691

Yochum LA, Folsom AR, Kushi LH (2000) Intake of antioxidant vitamins and risk of death from stroke in postmenopausal women. Am J Clin Nutr 72(2):476-483

Zandi PP, Anthony JC, Khachaturian AS, Stone SV, Gustafson D, Tschanz JT et al (2004) Reduced risk of Alzheimer disease in users of antioxidant vitamin supplements: the cache county study. Arch Neurol 61:82-88

Zingg JM, Azzi A (2004) Non-antioxidant activities of vitamin E. Curr Med Chem 11(9):1113-1130 